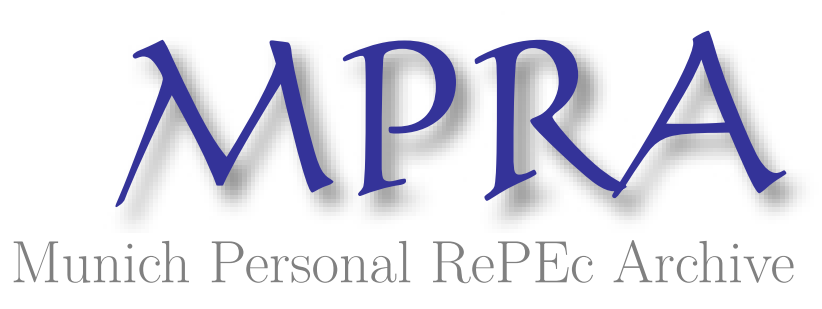

\title{
China's Household Balance Sheet: Accounting Issues, Wealth Accumulation, and Risk Diagnosis
}

\author{
Li, Cheng
}

Institute of Economics, Chinese Academy of Social Sciences,

National Institution for Finance and Development, China

26 June 2017

Online at https://mpra.ub.uni-muenchen.de/79838/

MPRA Paper No. 79838, posted 26 Jun 2017 04:25 UTC 


\title{
China's Household Balance Sheet: Accounting Issues, Wealth
}

\section{Accumulation, and Risk Diagnosis}

\author{
Li, Cheng ${ }^{1}$
}

\begin{abstract}
In this paper, we compile China's household balance sheet and apply this perspective to the analysis of household financial conditions. Specifically, we first address some technical issues on the balance sheet accounts, and detail the estimations of two important asset items, "dwellings" and "automobiles." Next, through reading the sheets, we provide an international comparative analysis, and show: (1) China's households are still on their early stage of wealth accumulation, and this trend is associated with a changing structure in favour of financial assets. (2) Although being subject to relatively low insolvency and liquidity risks, the sector has experienced, generally contrary to major developed countries, a climbing leverage cycle since the global financial crisis. These findings imply that China's policymakers should, on the one hand, make further efforts to help households accumulate wealth with an improved structure in terms of liquidity and risk diversification, and on the other hand need to pay high attention to the increasing household financial stress and the potential risk contagion.
\end{abstract}

JEL classification: E01; E21; O57

Keywords: Balance sheet; Household sector; Wealth accumulation; Debt risks; Financial deepening

\section{Introduction}

National and sectoral balance sheets provide an important stock perspective, which is particularly informative about aggregate wealth accumulation, financial superstructure, debt risks and their transmission mechanisms, as well as other macroeconomic issues. Early works include Dickinson and Eakin (1936), Goldsmith and Lipsey (1963), Revell (1966), and Goldsmith (1982), which offered estimates and descriptive analyses on the balance sheets of some major developed economies. To a large extent, because of the lack of official statistics and well-established theoretical frameworks, the above research did not draw much attention from scholars and policy

\footnotetext{
${ }^{1}$ Institute of Economics, Chinese Academy of Social Sciences; National Institution for Finance and Development, China. Postal address: No.2, Yuetan Beixiaojie, Xicheng District, Beijing, China, 100836. Email: licheng@cass.org.cn. The author thanks Xin Chang, Olivier Frécaut, Yang Li, Xueliang Liu, Thomas Piketty, Li Yang, and Xiaojing Zhang for their valuable comments and suggestions.
} 
makers at that time, perhaps with the "financial interrelation ratio" as a remarkable exception (Goldsmith, 1982) ${ }^{2}$. Nevertheless, in the aftermath of frequent financial turmoil in Latin American and East Asia over the 1980s and 1990s, the limitations of the conventional macroeconomic analysis based upon flow indicators, such as Gross Domestic Product (GDP) and factor inputs, become more apparent, while the stock perspective, such as macro-level balance sheets, gains increasing attention among academia. In this respect, influential research lines and topics include the "balance sheet approach (BSA)" to financial crisis (Allen et al., 2002, Rosenberg et al., 2005, Lima et al, 2006, Mathisen and Pellechio, 2006, and Reinhart et al., 2014), the risk contagion through balance sheet channels (Kiyotaki and Moore, 2002, Gray et al., 2007, Ahrend and Goujard, 2012, and Paltalidis et al., 2015), the balance sheet adjustments in business cycles (Caballero et al., 2008, He et al., 2010, Koo, 2011, Eggertsson and Krugman, 2012, and Nuño and Thomas, 2017), and the balance sheet-based wealth analysis (Piketty, 2014, and Piketty and Zucman, 2014) ${ }^{3}$.

In the years following the Global Financial Crisis, besides the scholarly community, there is also an increasing consensus among international organisations and policy makers on the importance of national/sectoral balance sheet statistics and their implications for financial stability and surveillance. In this regard, a promising step is the Data Gaps Initiative, which was launched in September 2009 by International Monetary Fund (IMF) and Financial Stability Board (FSB) as a response to the call of the Group of Twenty (G20) made in April of the same year. This initiative includes a set of twenty recommendations aimed at improving the collection, disclosure, and application of macro-financial data, of which some have direct relevance to the balance sheet accounting and analysis ${ }^{4}$.

As for China, the balance sheet perspective had received little attention before the 2008 crisis, with the exception of the National Bureau of Statistics of China (NBSC), who published two guidebooks on the conceptual frameworks and methods of compilation of national/sectoral balance sheets in the case of China (NBSC, 1997 and 2007). However, according to NBSC, balance sheet serves only, loosely speaking, as an intermediary accounting component within the system of national accounts, and thus regular data release on this account has not been established yet. To a large extent, it was not until the global financial tsunami and the subsequent European debt crisis that China's macro-financial conditions, especially debt stress, have emerged as focuses of academic and policy attention. Obviously, information and analysis on the stock variables, such as assets and liabilities, are sorely needed to address these emerging concerns. In this context, a few scholars, including Liu et al. (2009), Cao and Ma (2012), Li et al. (2012a, 2012b, 2013, 2015), Ma et al. (2012), and Du et al. (2015) compile and examine China's national/sectoral balance sheets. A recent attempt has been made by Piketty et al. (2017), which focuses on the accumulation of wealth and economic

\footnotetext{
2 Typically, it is defined as the ratio of financial to tangible assets, measuring the level of financial deepening.

${ }^{3}$ It is noteworthy that besides the balance sheet perspective, our paper is also closely related to the research line of "household finance," which, as recently pointed out by Guiso and Sodini (2013), has become an emerging independent field.

${ }^{4}$ Mainly referring to the recommendations No.15 to No.19. See http://ec.europa.eu/eurostat/statisticsexplained/index.php/G20_Data_Gaps_Initiative_(DGI)_-_background.
} 
inequality in China. In their work-in-progress, some tentative estimates for private and public wealth are provided with reference to the aforementioned studies on China, especially Li et al. $(2013,2015)$ and $\operatorname{NBSC}(1997,2007)$. On the whole, for the time being this growing body of literature is still in its infancy, and in particular, in-depth sector-focused investigations and international comparative studies remain largely preliminary.

With the aim of contributing to this important and emerging research area, the current paper addresses the balance sheet of China's household sector. The choice of this subject-matter is chiefly for three reasons: First, the financial conditions of China's households - the most important holder of national wealth both in China and major developed economies - have direct implications for some macroeconomic issues of paramount importance, especially including wealth/income distribution, household financial behavior and its impact on financial stability. Second, through its association with financial institutions and housing market, the household balance sheet provides an irreplaceable angle for looking at the two crucial challenges facing China today, the "deleveraging" of debts and "destocking" of real estate inventories ${ }^{5}$. Third, compared to other sectors, especially public sector, the asset and liability items of household sector are more clearly defined, thereby not only facilitating the compilation of the balance sheet, but also rendering the relevant international comparison more reliable.

The rest of the paper proceeds as follows: Section 2 provides an overview of the accounting framework of China's household balance sheet and shows the compiled sheets for the years 2004 to 2014. Section 3 presents the estimation methods of "dwellings" and "household automobiles," which, put together, constitute the quasitotality of household holdings of non-financial assets. Next, from comparative perspectives, Section 4 discusses the net wealth accumulation of China's households; and Section 5 examines the financial conditions and risk profiles of the sector. The last section concludes the paper by discussing China's policies on household wealth accumulation and the related risk management. Caveats and suggestions are also given for future research.

\section{Major accounting issues about China's household balance sheets}

According to China's system of national accounts (NBSC, various issues), "household" sector in China refers to the aggregation of urban and rural households, and individual businesses. Conceptually, this definition is a slight variant of the one proposed in the well-accepted System of National Accounts 2008 (SNA 2008), which includes "residents" albeit without urban-rural distinction, and "unincorporated enterprises." The sector is also defined in a similar manner in some major developed countries, such as the Group of Seven members and Australia. However, among them, Canada, Germany, the United Kingdom (UK), and the United States (US) only report the combined balance sheet statistics on households and "non-profit institutions serving households" (NPISH), thus reducing the comparability across countries. Thankfully, given the small size of the NPISHs relative to households, this problem seems to have

\footnotetext{
${ }^{5}$ See http://www.chinadaily.com.cn/bizchina/2016-04/01/content_24224454.htm.
} 
a limited impact on our comparative analysis shown in next sections of the paper ${ }^{6}$.

Regarding the sheet structure, main entries, and valuation methods, we draw basically on the NBSC (2007) and the SNA 2008, whereas some technical adjustments and assumptions have been made so as to accommodate the case of China and the purpose of our research regarding wealth and financial risk analysis. In view of that, the household balance sheets compiled by us can be viewed as an alternative picture rather than an approximation of the official figures, which remain unfortunately unavailable at the time of writing.

Given the data limitations, especially on the statistics of assets, we only compile the annual sheets for the period of 2004 to 2014 (year-end figures), in which China's economy witnessed a shift from high-speed growth to medium-high speed growth, and other structural transformations both on supply and demand sides (see Zhu, 2012). It is important to mention that those changes serve as the background for our understanding of the characteristics and dynamics of China's household financial conditions. The estimated balance sheets are then shown in Table 1.

\section{[Table 1 around here]}

As can be seen from the table, following the SNA standards, the balance sheet breaks down into assets, liabilities, and their difference, net worth. On the side of assets, the first category pertains to the non-financial assets. Following Liu et al. (2009), only three items of produced assets are considered: "dwellings" and "household automobiles" "which are based upon our estimations detailed in the next section, and "productive fixed assets of rural household" which is released by NBSC (various issues). At this juncture, it is noteworthy that land and other natural resources in China are de jure owned by the state and the collectives. Hence, in the spirit of SNA 2008 that stresses the ownership rights and their effective enforcement on economic resources by the institutional unit in question (Chapter 10, Section 10.167), these items should not be seen as household properties (also see European System of Accounts 2010, Chapter 7, Section 7.26) ${ }^{8}$. It must also be indicated that the treatment of non-produced tangible assets, including land and other natural resources in national / household balance sheet accounts substantially varies among countries. Taking "land" as an example: the "land underlying buildings and structures" is combined with real estate items in the case of Australia, the UK and the US; the land of same kind is separately reported in the case of France and Germany; this item is absent in the case of Canada, where "land" refers

\footnotetext{
${ }^{6}$ For instance, in 2015 , the total assets of the NPISH are merely equivalent to $1.2 \%$, and $4.5 \%$ of those held by the households in France and Japan, respectively.

${ }^{7}$ Indeed, as recommended by SNA 2008 (Chapter 13), consumer durable goods "are not treated as being used in a production process giving rise to household services"(p.269), and therefore, they should not be shown on the side of assets in the balance sheet. However, since consumer durables have important relevance to wealth accumulation, risk profiles, and consumption/saving behaviour, we still treat it, as it is also the case for Canada, France, Italy, the UK and the US - as an asset item rather than a "memorandum item." In view of that, to homogenize the balance sheet data, in this paper we reintroduce consumer durables on the side of assets in the case of Australia and Germany. In the case of Japan, only two items of produced assets, namely "fixed assets" and "inventories," are reported, and thus housing assets and consumer durable goods are not distinguishable.

${ }^{8}$ It is to note that Piketty et al. (2017) assume a partial ownership of farmland between rural households and government sector in China: the share of the former is assumed to increase from 30\% to 60\% during 1978-2015.
} 
mainly to agricultural land; no details have been given about the coverage of "land" in the case of Italy and Japan. Despite its nontrivial effect on the composition of household non-financial assets, it seems to affect little the total value of this category of assets (and thus, net worth) ${ }^{9}$.

The second category of assets pertains to the "financial assets," composed of eleven items: "currency," "deposits," "bonds," "shares," "shares in investment funds," "margin account in securities company," "insurance reserve fund," "financial products," "trust fund," "settlement fund," and "other financial assets." The figures on this category are directly sourced from "financial balance sheet of China's households" in China Financial Stability Report (CFSR) by People's Bank of China (PBoC, various issues) for the period of 2004-2010. Starting from 2011, they are estimated by adding current "flows" into the stock in previous year, which are sourced from Flow of Funds Accounts (FFAs) released in NBSC (various issues) ${ }^{10}$. It is to note that both CFSR and FFAs do not report the equities of unlisted corporations held by households. In this paper, in most cases we still make use of the "CFSR + FFAs" data. In other cases, we consider the aggregation of listed and unlisted corporation equities held by households, which is estimated as follows: We first take the estimates of corporation sector's net worth provided in Li et al. (2015, Chapter 7), which are on the basis of China Economic Census (took place in 2004, 2008 and 2013) and FFAs. Next, we assume the share of households in the holdings of equities equals the share of private agents in "total investment in fixed assets" released in Statistical Yearbook (NBSC, various issues).

On the side of liabilities, according to the NBSC (2007), they refer exclusively to loans, which include "non-operating loans" (for urban and rural residents), and "operating loans" (for individual businesses). Each category has further been classified as "short-term loans" (consistent with the criterion proposed in SNA 2008, namely original maturity of one year or less), and "mid/long-term loans" (longer than one year). The data on liabilities for years 2004-2006 are directly sourced from CFSR, and those for years 2007-2014 are sourced from the tables of "sources and uses of credit funds of financial institutions" released by $\mathrm{PBoC}^{11}$. It is noteworthy that some liability items recommended in the SNA 2008, such as "debt securities," "insurance, pension and standardized guarantee schemes," and "other accounts payable" are omitted in the case of China. Logically, this omission also leads to underestimating, albeit to a small extent, the size of household liabilities. ${ }^{12}$

\section{Estimations of "dwellings" and "household automobiles" assets}

To estimate the market value of "dwellings (excluding land under dwellings)" and "household automobiles", we draw mainly upon the methods taken in Li et al. (2013, Chapter 16), which will be briefly presented in what follows with supplementary and updated information. Our estimates will also be compared with those given in another

\footnotetext{
9 Due to data limitations, "intellectual property products" are also excluded in the case of China. Given the fact that this item, in general, represents a negligible part in household assets $(0.14 \%$, in the case of US for the year of 2015), the bias resulted from this exclusion seems to be minor.

10 The data on "financial products" and "trust fund" over 2011-2014 are still sourced from CFSR.

11 The data on "mortgages", which only include commercial housing loans, are sourced from CFSR.

12 Again, for instance, "loans" account for more than $96 \%$ of the US household liabilities in 2015.
} 
relatively comprehensive analysis on China's macro-level balance sheets, namely Ma et al. (2012).

\subsection{Dwellings}

Given the dual urban-rural structure in China, especially in terms of legal status of lands and Hukou system (see Ho and Lin, 2003), "dwellings" in urban and rural areas are estimated in two different procedures. For the former, the compilation is based upon the data about "floor space per capita," "average selling price of new residential buildings," and "urban population," which are all reported in China Statistical Yearbook (NBSC, various issues). We also apply the straight-line depreciation method to the calculation of the market value of dwelling stock. It is to note that no depreciation adjustment has been applied to the series in and before 1978 due to data limitations. Given the small size of housing stock in the pre-1978 era and the relatively large timespan between 1978 and our sample period, this problem, albeit giving rise to a bias of overestimation, seems to have trivial effect on the dwelling values over the sampled years. ${ }^{13}$ Finally, according to news reports, on average, urban dwellings in China have an actual service life of about 30 years and a designed lifespan of 50 years. In view of that, we choose a yearly depreciation rate of $2.4 \%$ in this paper ${ }^{14}$. More specifically, the estimation procedure can be summarized as follows:

Total Value of Urban Dwellings $\mathrm{s}_{\mathrm{t}}=\mathbf{\alpha} \boldsymbol{\beta}^{\prime} p_{t}$,

$\mathbf{\alpha}=\left(A_{t}, A_{t-1}, \ldots A_{1979}\right)$,

$\boldsymbol{\beta}=(1,0.976, \ldots(1-0.024 n), n=t-1979$,

where $A t$ denotes the newly added floor space in year $t ; \boldsymbol{\beta}$ denotes the depreciation vector; $p t$ denotes the average selling price of residential buildings in year $t$.

Turning to the estimation of the rural dwelling assets, we draw upon the information released by NBSC (various issues), which include the "floor space per capita," "rural population," and "value of houses (per square meter)" at year-end. Since the latter corresponds, arguably, to the replacement costs of rural houses, this series can be taken directly with no need of depreciation adjustment.

Figure 1 allows a comparison of our estimates with those given by Ma et al. (2012, Chapter 5) and Piketty et al. (2017). The former relies on the replacement costs of both urban and rural dwellings, and the latter draws upon Li et al. (2013, Chapter 16) with some adjustments, especially on depreciation methods. As can be seen from the figure, first, however different the methods of compilation are, the estimated total values of dwellings do not substantially differ between Ma et al. (2012) and ours, with a discrepancy ranging from $13 \%$ in 2006 to $0.3 \%$ in 2009 . Nevertheless, it seems noteworthy that their estimates tend to be slightly greater than ours in every year under consideration. Unfortunately, since no much details have been revealed in that study, we cannot further account for this discrepancy. Second, although the work of Piketty et

\footnotetext{
13 In fact, the total floor space of urban dwellings in China amounts only to 1.16 billion square meters in 1978, namely less than one-twentieth of that in 2014; see Li et al. (2013, Chapter 16) for further explanation.

${ }^{14}$ See, for instance, http://news.china.com/zh_cn/domestic/945/20100419/15902148.html. Moreover, for reference only, if taking an annual depreciation rate of $2 \%$ (3\%, respectively), then the total value of urban dwellings will be 114 trillion yuan (97 trillion yuan) in 2014 .
} 
al. (2017) and ours are undertaken in much the same spirit, their estimates (both on urban and rural) tend to substantively larger than ours and those of Ma et al. (2012). Arguably, it seems that this remarkable discrepancy cannot be entirely attributed to different depreciation methods. ${ }^{15}$ It is hoped that we could come up with a better explanation for this as their preliminary work is being refined and improved.

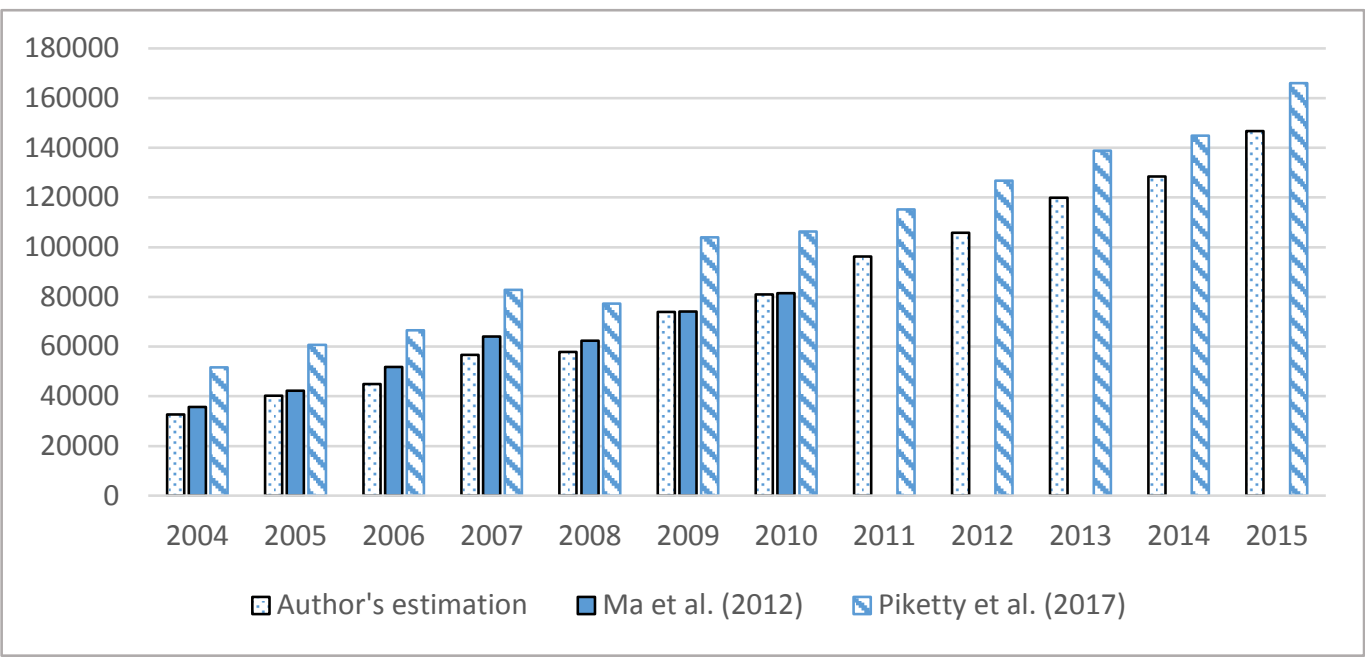

Figure 1: Estimations of Urban and Rural "Dwelling" Assets (in billion yuan)

Note: the values of urban and rural dwellings are estimated to reach 122.79 trillion yuan, and 23.92 trillion yuan, respectively, in 2015 .

\subsection{Household automobiles}

In much the same spirit of Liu et al. (2009), the value of "household automobiles" is estimated as follows:

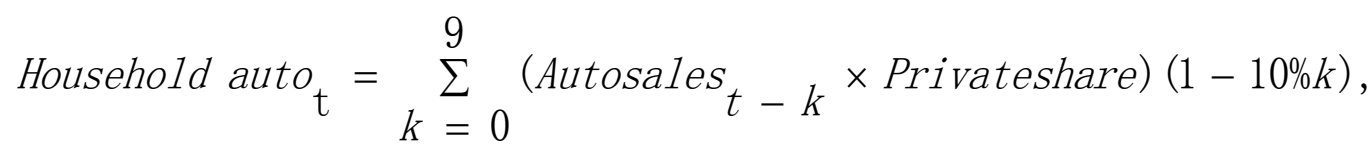

where the sales of automobiles of all kinds (or prime operating revenues of automotive products) come from China Automotive Industry Yearbook (China Association of Automobile Manufacturers, various issues); the Privateshare, denoting the average share of private vehicles in the total civil vehicles during the period of 2004-2014 (from NBSC, various issues), is set to $76 \%$. The value is then depreciated on straight line basis over 10 years. The latter is, as argued in Liu et al. (2009), the approximate average lifespan of a vehicle in major developed countries ${ }^{16}$.

At this juncture, it is to note that Ma et al. (2012, Chapter 5) also provide estimates of "consumer durables" over 2002-2010. Their figures are substantially smaller than ours about household automobiles in the early years of the sample, and then, by reaching 4.73 trillion yuan, surpass ours in 2010 (4.46 trillion yuan). Like in the case

\footnotetext{
${ }^{15}$ For example, a $2 \%$, rather than $2.4 \%$, annual depreciation rate is used in Piketty et al. (2017) for urban house; depreciation adjustments are also done with the pre -1978 series in their study.

${ }^{16}$ For reference, the value of household automobiles is estimated to reach 8.94 trillion yuan in 2015.
} 
of housing assets presented above, since no details have been given on the definition of this item and its data sources in Ma et al. (2012), we are unable to judge the accuracy of their results.

\section{Household net worth analysis}

By construction, the "net worth" refers to the difference between total assets and liabilities, measuring the wealth which is composed of non-financial assets and net financial position. In Table 2, we briefly compare our estimates with those given by other four studies on the topic: (1) Liu et al. (2009), which directly inspires the current paper regarding conceptual framework and method of compilation; (2) Ma et al. (2012), which relies on, like ours, macro-level official statistics; (3) Xie et al. (2014), which relies on a micro-level survey, namely China Family Panel Studies, conducted by a Peking University research team; (4) Piketty et al. (2017), which draws, to some extent, upon the methods proposed in NBSC $(1997,2007)$, and Li et al. $(2013,2015)$.

\section{[Table 2 around here]}

On the whole, the estimates from Ma et al. (2012), Xie et al. (2014), and current paper differ slightly both in level and trend, whereas Liu et al. (2009) and Piketty et al. (2017) report remarkably larger figures. As for Liu et al. (2009), by way of conjecture, this discrepancy might be attributed to the fact that those authors did not conduct the depreciation adjustment regarding the value of urban houses. The latter, only available during 2004 to 2007 , is about $25 \%$ higher than ours over the same period. As for Piketty et al. (2017), their estimation methods differ from ours in many aspects, and two of which are particularly noteworthy. First, as mentioned in footnote 8 , they include farmland assets which are assumed to be shared between rural households and government sector. Second, they include private equities of unlisted corporations. As shown in the table, if the farmland assets are excluded, Piketty and his coauthors' estimates are highly close to ours if including more comprehensive equities (referred to as "adjusted net worth").

We next mark three important features of the household wealth accumulation in China by comparison with the eight aforementioned economies, which regularly release national/ sectoral balance sheet statistics. First, as illustrated in Figure 2, households occupy a much smaller share in the total net worth (in terms of both unadjusted and adjusted) in China than in the economies of reference ${ }^{17}$. There are at least three major reasons for this: First, it can be read as the accumulating result of the fact that the labour's compensation - as the primary source of family income - generally occupies a smaller share in national income distribution in China than in developed countries. For instance, according to the Conference Board Total Economy Database ${ }^{\mathrm{TM}}{ }^{18}$, over the period of 1995-2015 the average "share of total labour compensation in GDP" for China is only $46 \%$, while those for the major developed economies in consideration range from 55\% for Australia to $61 \%$ for Germany and the US (see Bai et al., 2009, Chen,

\footnotetext{
${ }^{17}$ Italy is excluded from the analysis shown in Figure 2 due to lack of data on national net worth.

18 See http://www.conference-board.org/data/economydatabase/.
} 
2014). Second, the relatively small size of private wealth is also attributed to the dominant status of public sector (aggregation of general government, nonprofit public business, and state owned enterprises) in China's economy. Taking general government as an example, according to Li et al. (2015, Chapters 5 and 6), the net worth of the aggregation of central and local governments reached to 85 trillion yuan in $2013^{19}$, being 1.4 times of the country's GDP, whereas its counterpart in the sampled developed countries is usually very small relative to the size of their income or wealth (such as in France and Germany) or even exhibits negative value (such as in the UK and US). Third, relatedly, the fact that the land (both those under cultivation and under buildings) and other natural resources are not de jure owned by private agents in China also helps to explain the question in question.

In addition to the level, the dynamics of household wealth is also worthy of attention. As the figure shows, most countries considered here, including China, experienced a shrink in the household wealth size over 2008-2009. As for China, this phenomenon can be mainly attributed to the change in house prices, and to the fall in stock prices ${ }^{20}$. Moreover, generally speaking, the household sector in the sampled countries had recovered or at least stabilized in terms of wealth position as the global financial crisis ebbed, and thus showed somewhat resilience to shocks. In particular, the household shares in national wealth in the UK and the US regained their pre-2008 levels shortly after the height of the crisis (actually in 2009), whereas it was not until 2012 that this indicator in China returned to its 2007 level.

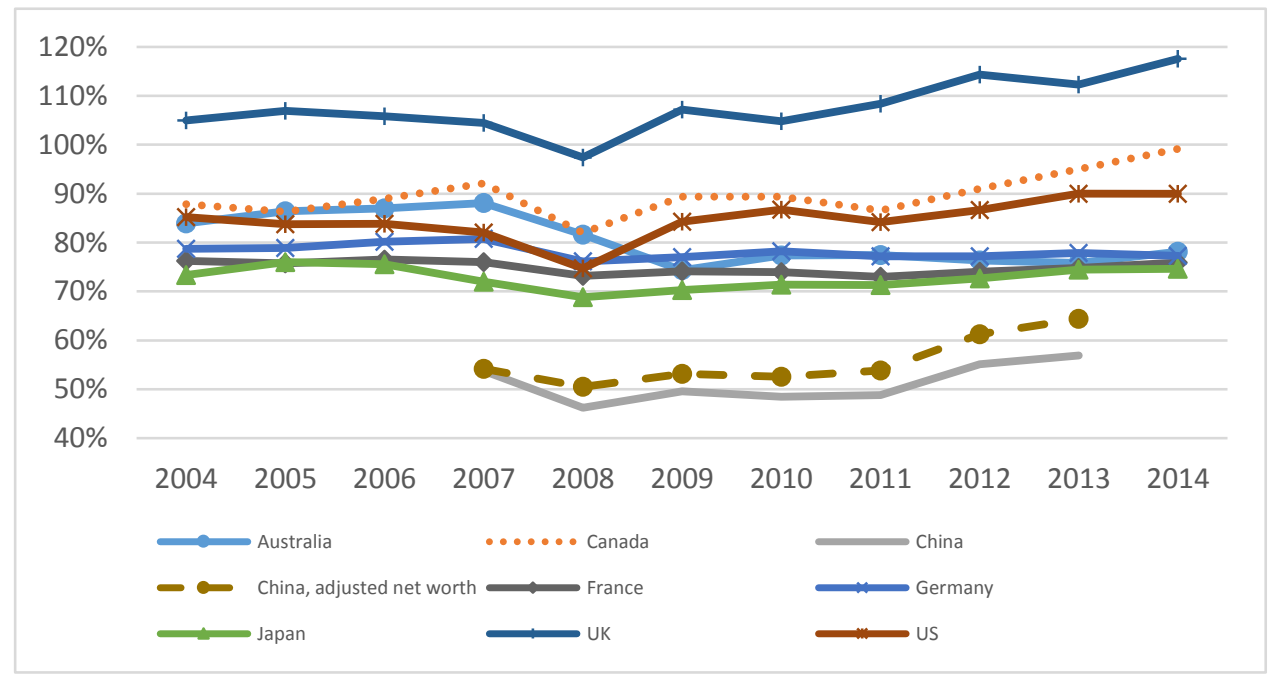

Figure 2: Shares of Household Net Worth in Total Economy (\%)

Data sources: Data on China's national net worth come from Li et al. (2013, 2015), in which the series ends in 2013; for data on other countries, see Appendix.

\footnotetext{
${ }^{19}$ It should be noted that Li et al. (2015, Chapters 5 and 6) and the current paper do not follow the same statistical framework and standards to compile the balance sheets of public sector and households, respectively. Thus, their estimates and ours cannot be directly taken to make a comparison of public-private wealth.

${ }^{20}$ As a matter of fact, in China the selling price of new residential buildings increased by, on average, about $10 \%$ annually over 2004-2015, whereas it decreased by $2 \%$ in 2008; the Shanghai Stock Exchange Composite Index was dramatically down to 1800 from 5200 in the single year of 2008 .
} 
Second, turning to the structure of the household wealth, we examine the share of nonfinancial assets in the net worth ${ }^{21}$. As shown in Figure 3, China's households tend to hold relatively large nonfinancial assets in their wealth position (even when land and other natural resources are not included), whose share in total net worth substantially surpasses those in Canada, the UK, Japan, and the US. Because of high trading costs of dwellings on the one hand (including costs associated with information, time, legal matters, and so forth), and the "lemon law" of secondhand vehicles (or consumer durables in general) sale on the other (Akerlof, 1970), this structural feature raises some concerns about the sector's exposure to liquidity risk (see Guiso and Sodini, 2013). Nevertheless, the figure also demonstrates that these shares in most countries under consideration have been on a downward trend over the past six years or $\mathrm{so}^{22}$, thus reflecting a financial deepening process in which households tend to allocate their resources through financial instruments, especially bonds and off-balance sheet financial products (li cai chan pin) in the case of China, rather than holding less liquid assets.

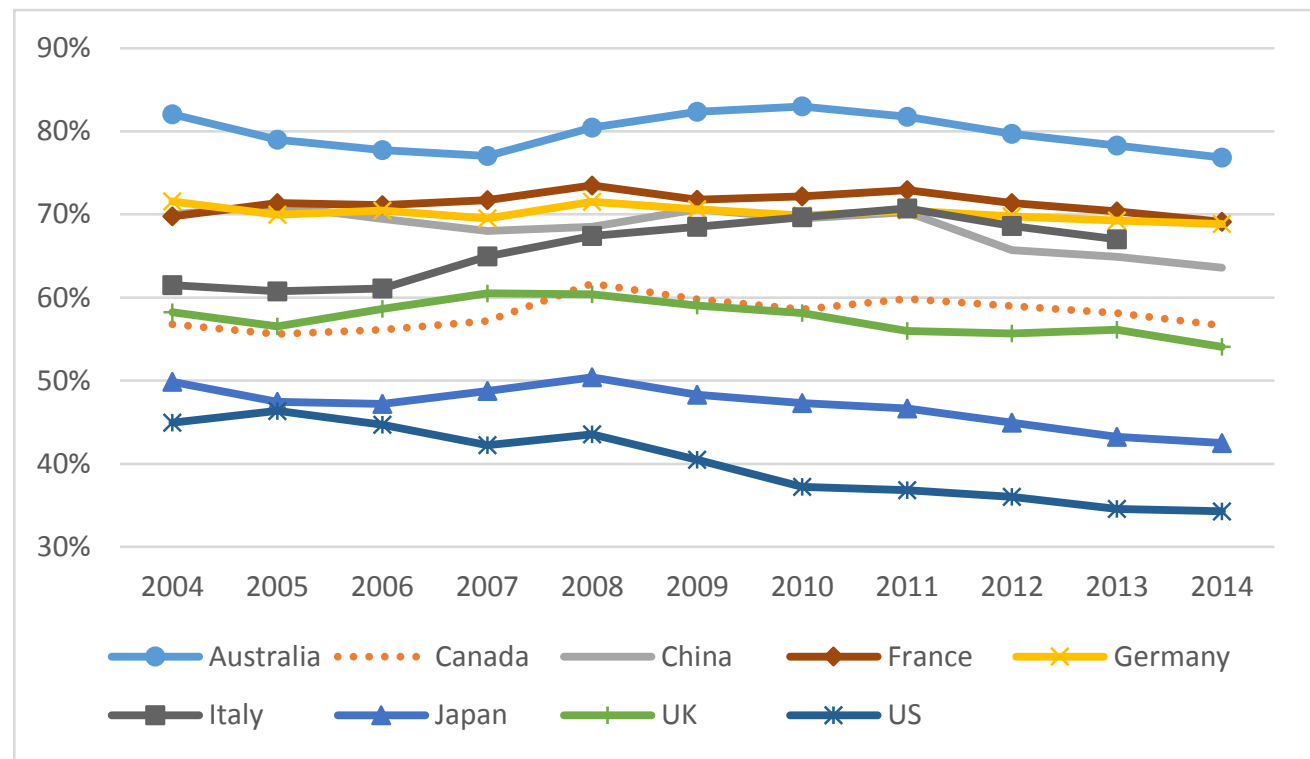

Figure 3: Share of Nonfinancial Assets in Net Worth

Data sources: see Appendix.

Third, we relate net worth (or adjusted net worth) to GDP (a flow/income indicator). The relation between the two variables can be first captured by the (household) wealth-income ratio, which draws much attention in the recent literature on capital accumulation and economic inequality (see Piketty, 2014, and Piketty and Zucman, 2014). As shown in Figure 4, to some extent, both China and the developed countries under consideration have experienced a somewhat similar trend in the wealth-

\footnotetext{
${ }^{21}$ For this purpose, we do not consider the equities other than "shares" and "shares in investment funds." Because although the equities of unlisted corporations are classified as "financial assets," they correspond to a mix of nonfinancial and financial assets in corporate sector, and by definition there is no market for these equities (see OECD, 2014, Chapter 8). Thus, they cannot be liquidated as easily as other financial assets.

${ }^{22}$ Notably, it also indicates a growing Goldsmith's financial interrelation ratio in the household sector.
} 
income ratio: it plummeted at the height of 2008 crisis, and has rebounded since then, with a mild downturn over 2010-2012 (except UK). Remarkably, in 2014, the adjusted net worth to GDP ratio in China is already extremely close to that in Germany. Moreover, what the figure shows about the case of China is also basically consistent with the findings provided by Piketty (2014) and Piketty and Zucman (2014). Based upon long term observations, these authors find that in major industrialized countries the wealth-income ratio declined in response to structural shocks such as the two World Wars and the Great Depression, and has gradually risen since the 1970s because of asset revaluation (mainly housing) and the slowdown of productivity and population growth. Interestingly enough, both reasons have emerged in China over the past few years, thus, arguably, explaining the recent rising wealth-income ratio in the country. However, it is also to stress that unlike Piketty and Zucman's studies, our sample period is surely too short to establish long term empirical regularity regarding the dynamics of wealthincome relation, and thus, the topic of whether China follows the same pattern as advanced countries is suggested as an interesting future avenue of research.

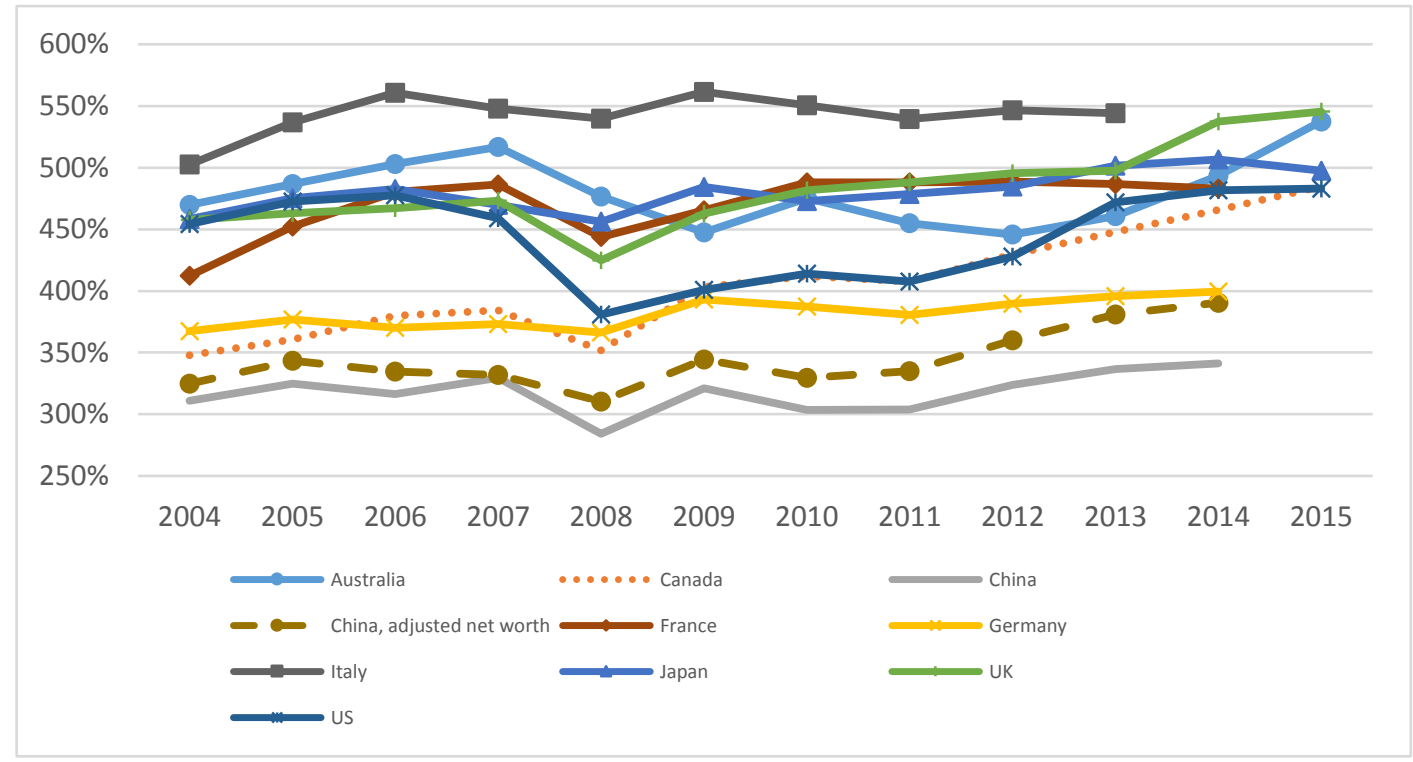

Figure 4: Household Net Worth to GDP Ratio

Data sources: GDP (current price) data come from World Economic Outlook Database, IMF; for wealth data, see Appendix.

From Figure 4, we can also gain some insight into the matching between wealth and income. Indeed, a straightforward implication of China's low wealth-income ratio is that if judged by the stock of wealth rather than flow of income, China's households appear to be less wealthy, and thus, more time and effort are needed to make China catch up the developed countries. For further illustration, in Figure 5 we compare China and the eight developed countries regarding both wealth and income in 2014 (2013 for Italy due to data availability), and find that the household wealth gap between China and the other countries is significantly larger than the income gap measured by GDP per capita. Arguably, three crucial factors can be taken to account for the wealth-income 
mismatching of such kind: first, it is well documented that China, as an emerging economy, has a relatively short history of wealth accumulation in modern era, and also develops from a starting-point of extreme poverty. The last two factors, both already mentioned, pertain to the small labour's share of income and the non-private ownership of land and other natural resources in China.

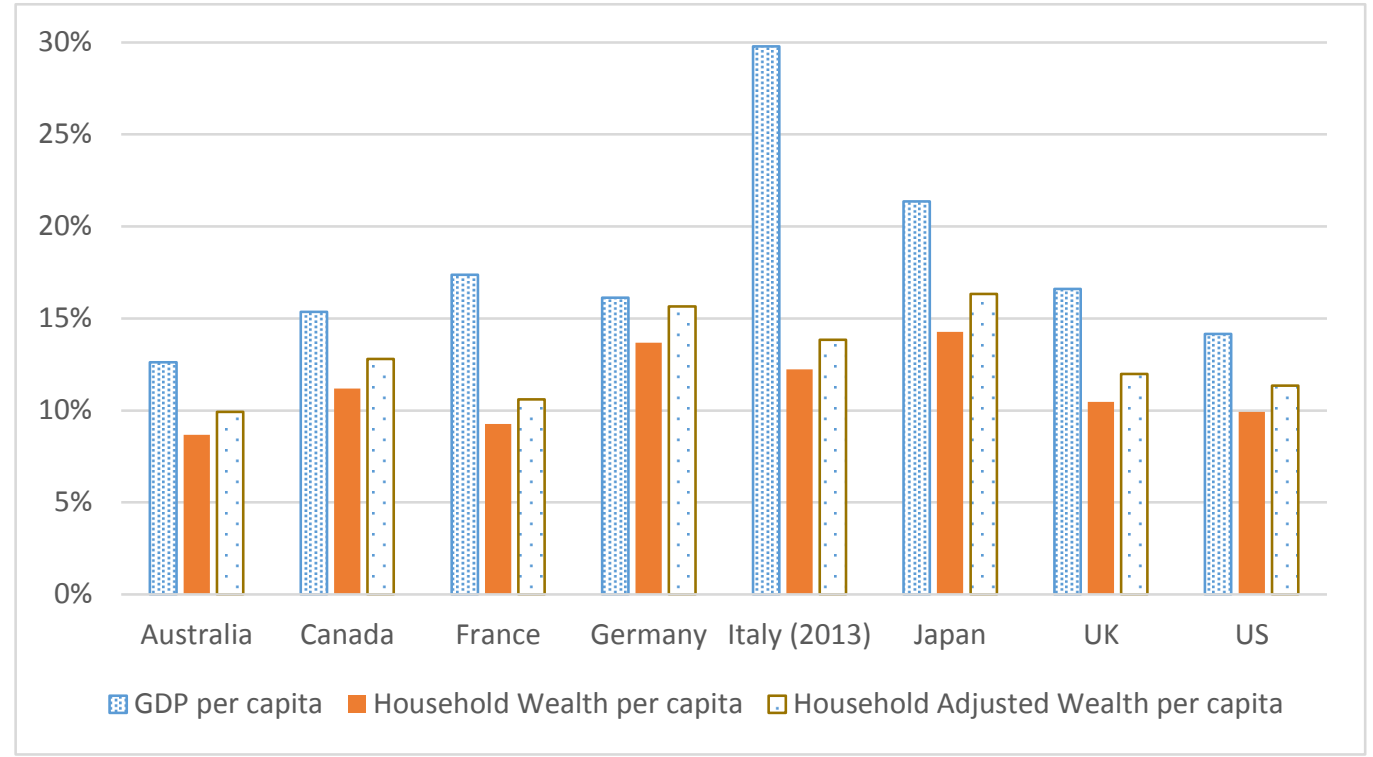

Figure 5: GDP per capita and Net Worth per capita in 2014 (China as \% of Corresponding Country)

Data sources: GDP per capita and population data come from World Economic Outlook Database, IMF; for wealth data, see Appendix.

\section{Risk diagnosis of China's households}

In this section, we examine the financial soundness and risks of the household sector through reading the balance sheet information. The first indicator is the "liabilities-to-assets ratio," which allows a picture of the household financing structure. As shown in Figure 6, the ratio in China remains below $10 \%$ over the whole sample period, being significantly lower than those in most developed economies in consideration (somewhat exceptionally, only slightly lower than the ratio in Italy). Judged from this perspective, an imminent insolvency risk for China's households seems less likely. Nevertheless, as also illustrated in the figure, the ratio has been increasing in the aftermath of the 2008 financial turmoil, indicating a rising trend of leverage. Roughly speaking, the phenomenon that China's households tend to borrow more compared to their assets can be attributed to various factors, either positive or worrying or mixed, including the development of consumption credit business, the mortgage loan expansion in the boom of housing market, and the changes in risk attitudes and consumption habits (especially for young generation). By contrast, in all other countries except Australia and Italy, households have witnessed a somewhat cycle of debt deleveraging after 2008, or, in other words, a process of "balance sheet repair," which is typical of advanced economies in a post-crisis context (see Koo, 2011). 


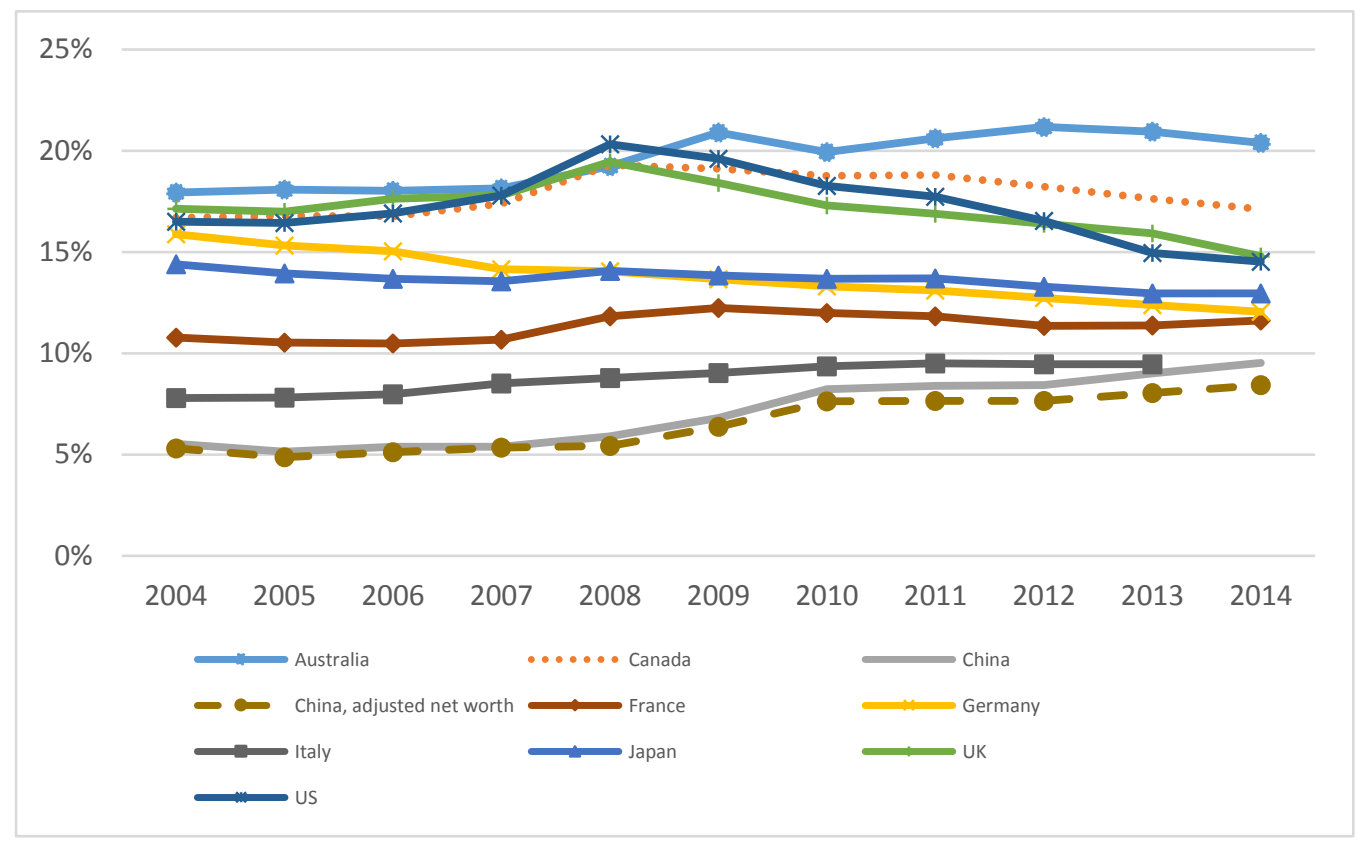

Figure 6: Liabilities-to-Assets Ratio (\%)

Data sources: see Appendix.

The structure of household financing can also be judged by liabilities-to-financial assets ratio, which helps to neutralize the concerns over the liquidity of nonfinancial assets, and, to some extent, the pro-cyclical character of the house prices which are high during economic upturns and low during downturns ${ }^{23}$. As shown in Figure 7, in Canada, France, Japan, the UK and the US, this liquidity-adjusted leverage measure still follows an inverted U-shaped trend, with the height of 2008 crisis as the infection point. Although in the three other countries, namely Australia, Germany and Italy, similar trend is hard to spot, they have all experienced a deleveraging cycle in recent years. By contrast, the ratio in China has nearly continuously increased since 2008, with the exception of the decline in 2012. At the end of our sample period, it overtook those in Japan and the US, and was comparable to that in Italy. Although the phenomenon might, as previously argued, result from a rapid financial development that provides individuals and families more access to credit, the climbing leverage ratio poses a serious threat to the household debt sustainability in China.

${ }^{23}$ For the same concern indicated in footnote 20 , here we do not consider the equities of unlisted corporations. 


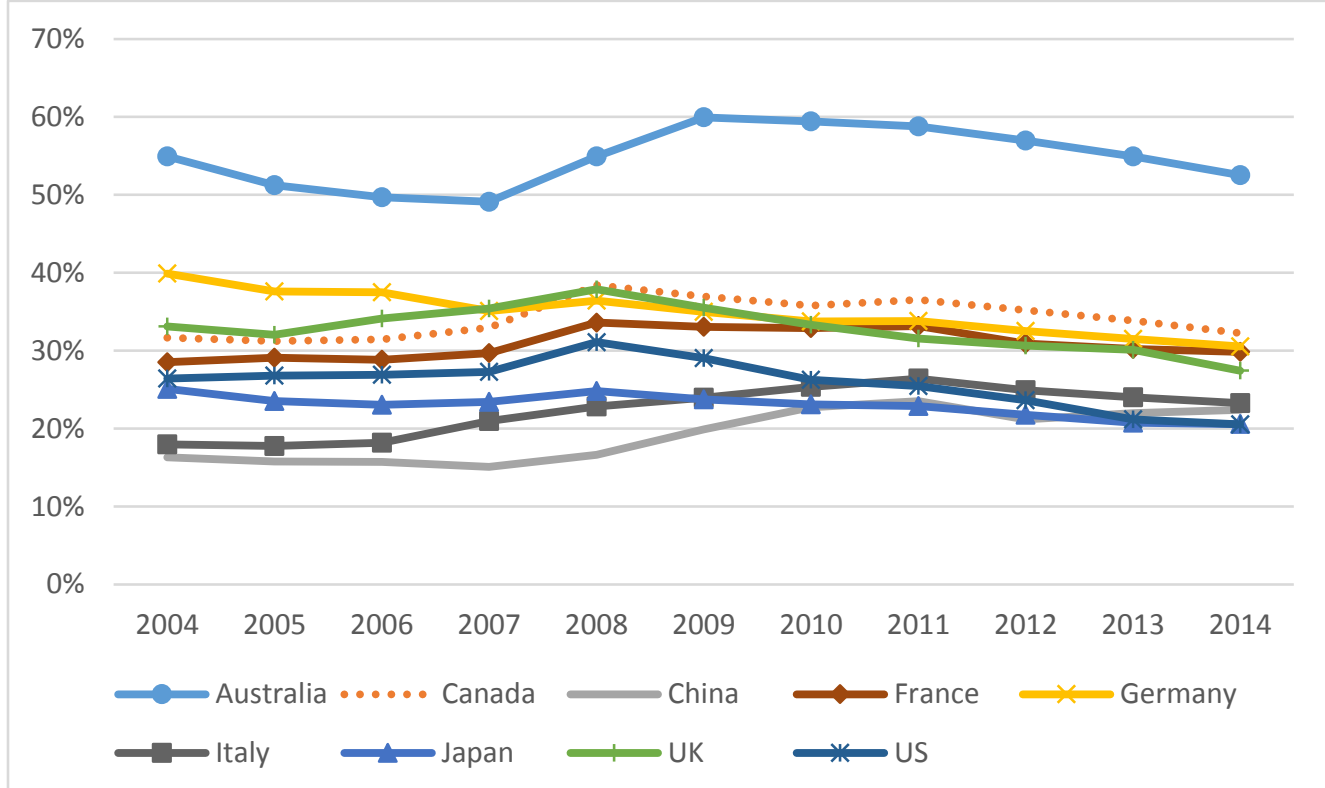

Figure 7: Liabilities-to-Financial Assets Ratio (\%)

Data sources: see Appendix.

In addition, focusing on the financial leverage involved in housing activities, which constitutes a topic of high attention in today's China, we examine the size and dynamics of housing loans (namely mortgages) with reference to dwellings' value. In particular, the experience of China can be better understood in comparison with those of Canada, Italy, and the US where the data on mortgages and housing assets are available in their balance sheet accounts. Clearly, as can be seen from Figure 8, the "loan-to-value ratio" of this kind in China is comparable to that in Italy, but remains largely below the levels of Canada and the US. This implies that households in both China and Italy, either actively or passively, adopt a more prudent (thus, less risky) house-financing strategy than their Canadian and US counterparts. However, there seems to be a signal of growing financial stress in China's real estate market since the 2008 crisis - similar to what has been observed about the liabilities-assets relationship. Indeed, the mortgages-to-dwellings ratio in China has nearly been doubled from $6 \%$ to $11 \%$ over 2008-2015, and also surpassed that in Italy from 2010. In the meanwhile, however, the ratio remains roughly stable in Canada, and even dramatically decreases in the US. 


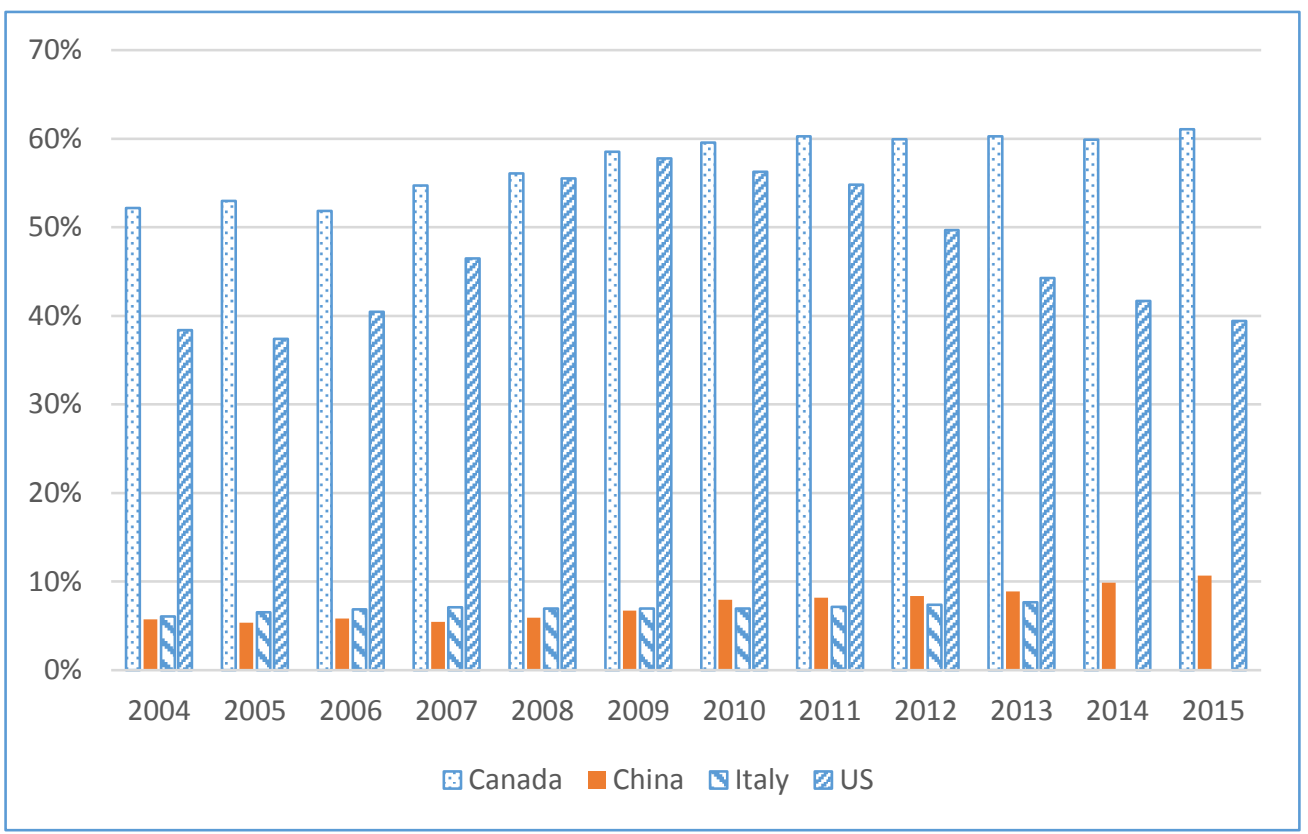

Figure 8: Mortgages-to-Dwelling Assets Ratio (\%)

Notes: 1. Data on mortgages come from PBoC (various issues); for other data, see Appendix.

2. In the case of China, "dwellings" refer to those owned by urban residents; "Mortgages" refer only to commercial housing loans, and thus, mortgages upon public accumulation funds (gong ji jin), being equivalent to approximately one quarter of the commercial loans in 2015, are excluded.

Next, we take a look at the ratio of liabilities (or debts) to household disposable income, which usually serves as a key measure of debt repayment capacity and thus has direct relevance for assessing the debt default risk. As illustrated in Figure 9, China's household sector has also followed an upward leveraging cycle since 2008 or so, and in recent years, the ratio has reached a level comparable to some developed countries including Germany and Italy. Also of importance, the increasing debts-income ratio in China, which raises worries about the sustainability of debts, is further associated with another disquieting phenomenon in terms of risk, namely a shortening maturity structure. Indeed, as shown in Figure 10, both the shares of long-term loans and of mortgages in the total non-operating loans in China have declined over the past ten years or so, and similar trend can also be seen in the case of US. These findings indicate that in both countries households suffer growing debt stress in the short run. Focusing on the case of China, arguably, this structural change results from, among other factors, the tightening up of mortgages and the booming development of credit card business during the observation period. 


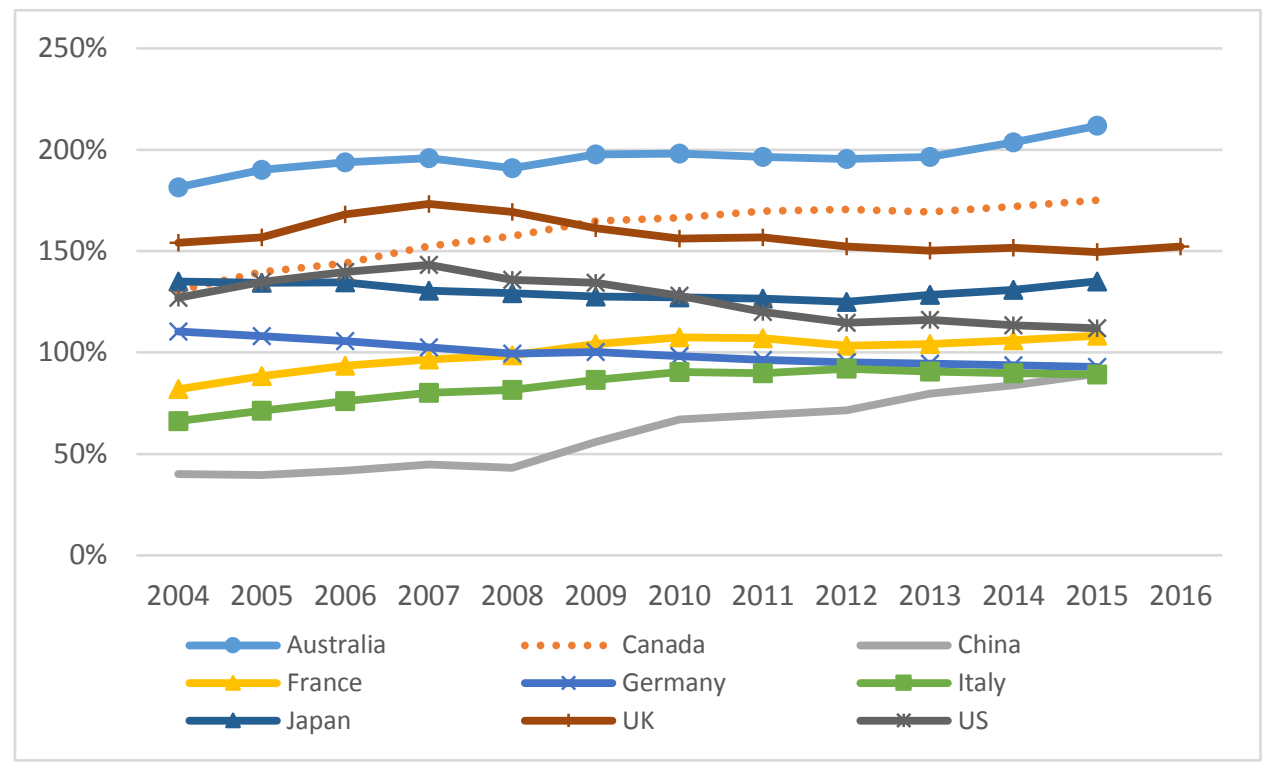

Figure 9: Liabilities (or Debts)-to-Disposable Income Ratio (\%)

Data sources: China data come from PBoC (for household debts) and NBSC (for disposable income); data of other countries come from National Accounts at a Glance, Organisation for Economic Co-operation and Development (OECD).

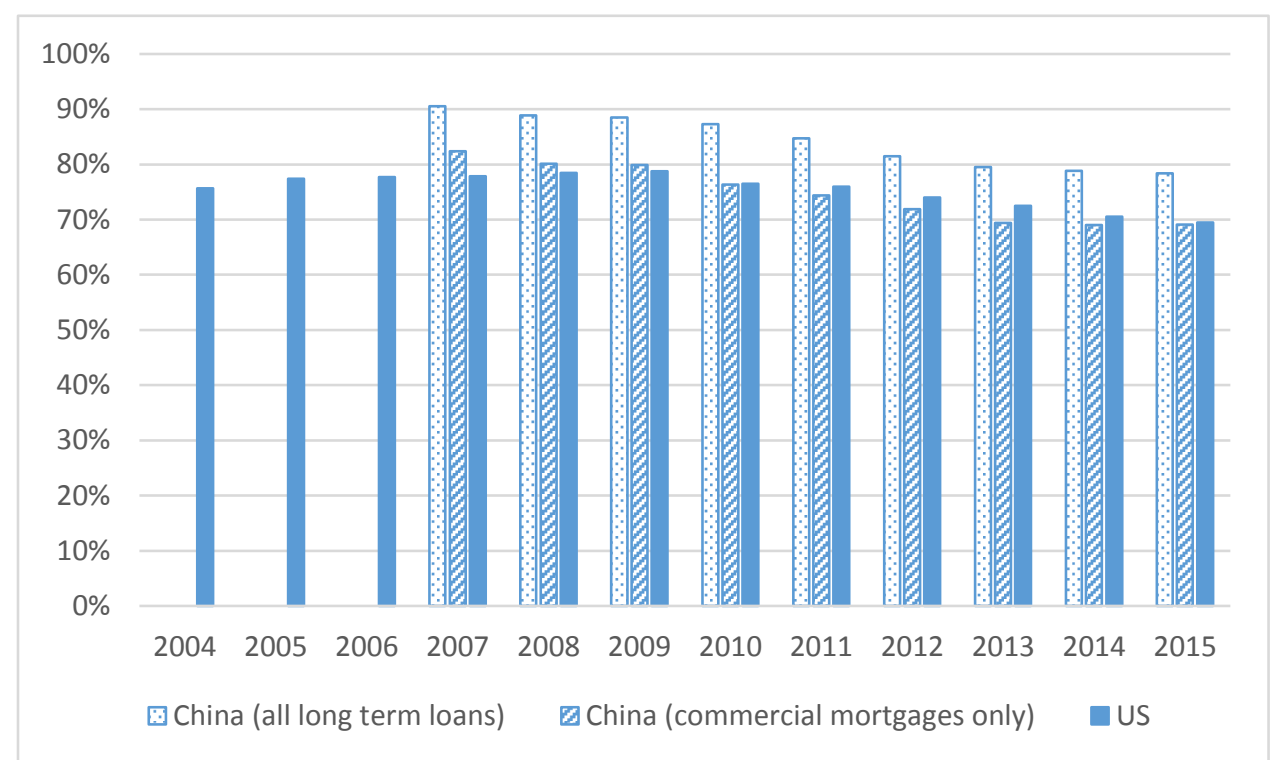

Figure 10: Long Term Loans or Mortgages as \% of Total Loans: China versus US

Notes: 1. For data sources, see Appendix.

2. In the case of China, only non-operating loans are considered.

3. In the case of the US, "long term loans" are equivalent to "mortgages."

As a final point, addressing the household defaults, we detect, in Figure 11, a somewhat U-shaped trend for the accumulation of nonperforming loans (NPL) in China (referring to the sum of three categories of loans, namely "substandard," "doubtful"" and "loss"). Indeed, within the past five years (2011-2015), the balance of the risky 
household loans in the country has been tripled in amount, with a NPL ratio (namely, NPLs to total loans ratio) climbing to $0.8 \%$ from $0.5 \%$. More specifically, as further shown in Figure 12, after decreasing during the period of 2007-2011, the NPL ratios of China's households for three major types of loans, namely bank card repayment, automobile credits, and mortgages, have all increased since then, albeit at a very slow pace for mortgages. Perhaps more important, this trend is associated with the aforementioned rising leverage process measured by several indicators, and thus becomes an added element of financial fragility in China. On the contrary, the US household default rates of all types have constantly declined since the height of the crisis, along with a financial deleverage cycle ${ }^{24}$.

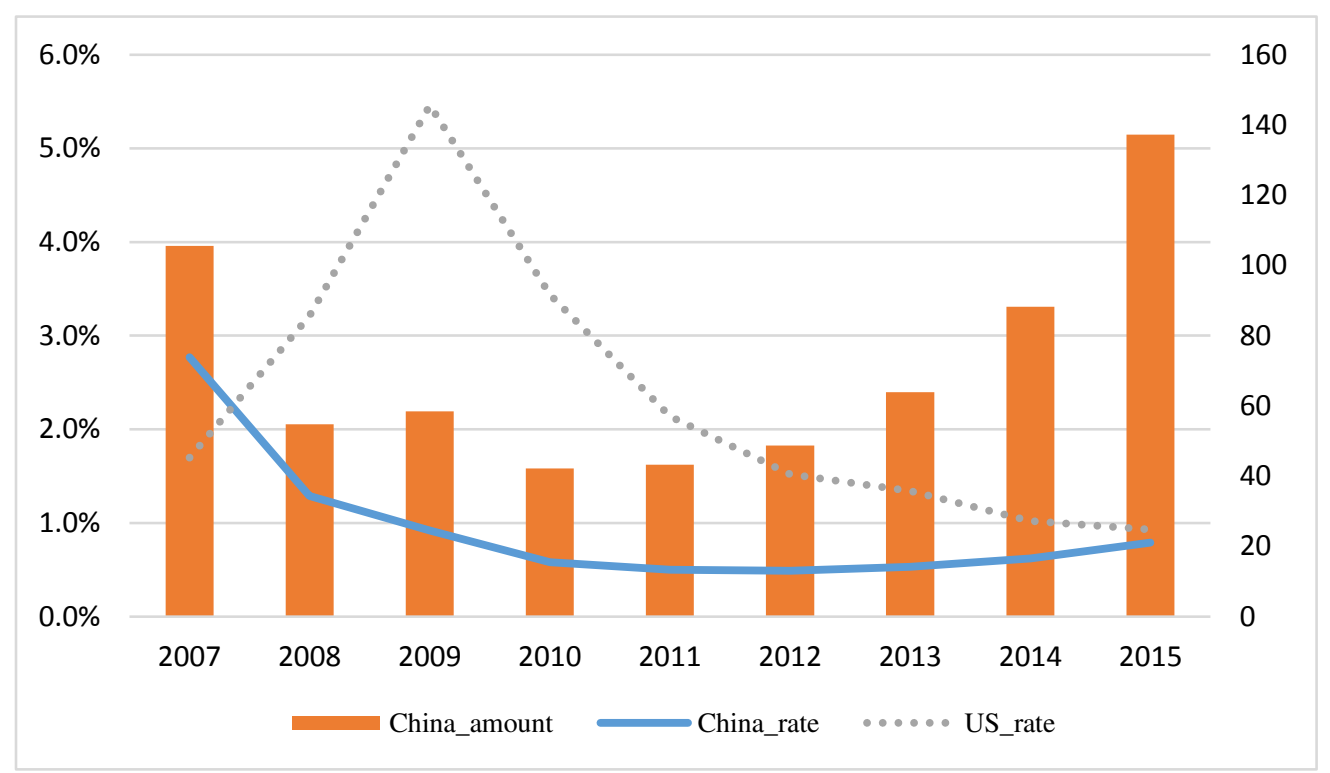

Figure 11: Household NPLs and Defaults: China versus US

Notes: 1. "China_amount" (in billion yuan, right hand axis) refers to the balance of the nonperforming household debts; "China_rate" (in percentage, left hand axis) refers to the NPL ratio. Loans to individual business are excluded from the statistics. "US_rate" (in percentage, left hand axis) refers to default rate, June data for each year.

2. China data come from China Banking Regulatory Committee Annual Report (various issues); US data come from $S \& P /$ Experian Consumer Credit Default Index Series.

\footnotetext{
${ }^{24}$ It is noteworthy that the NPL ratio and the default rate are highly related but not exactly comparable. In general, the former is greater than the latter, since not all NPLs will be in default eventually. Thus, as for the China-US comparisons shown in Figures 11 and 12, trend is more important than level.
} 


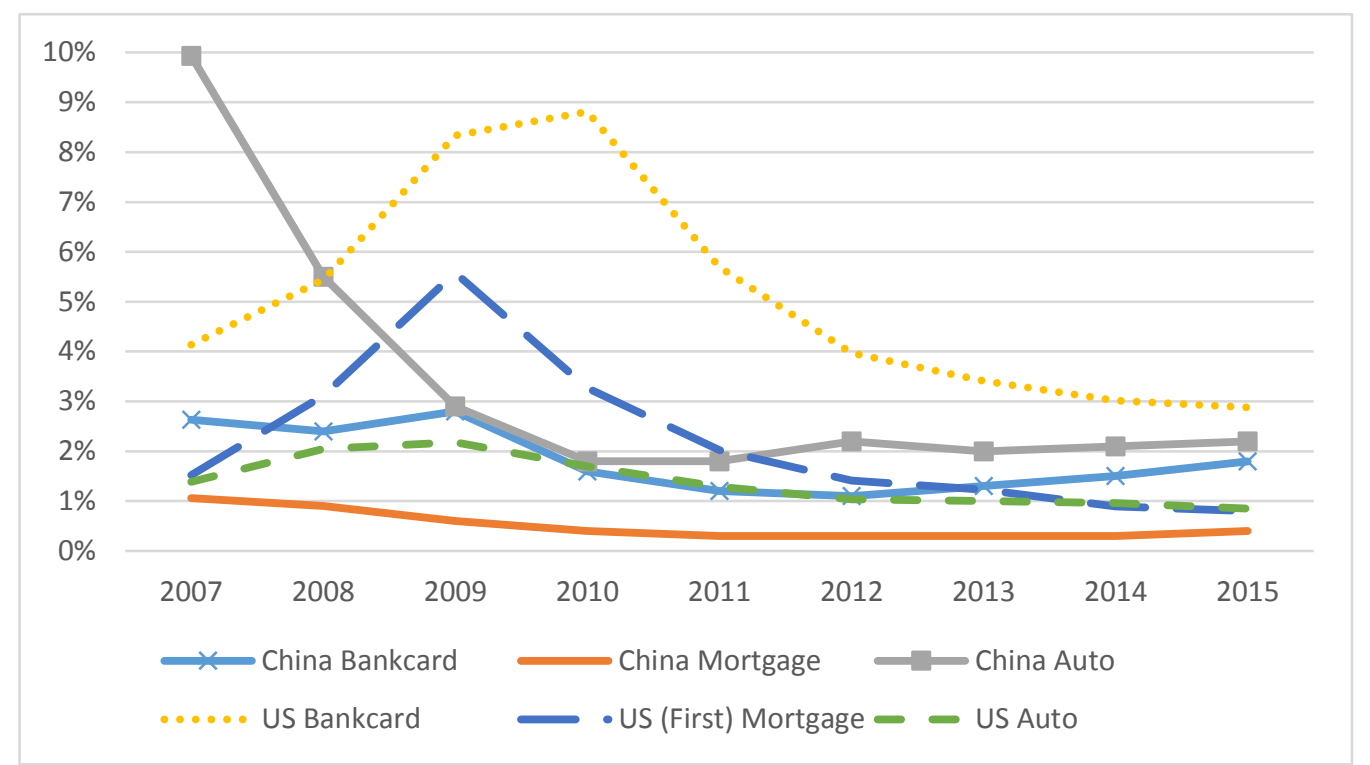

Figure 12: NPLs Ratios and Default Rates by Types of Debts: China versus US

Data sources: See Figure 11.

\section{Concluding remarks}

In this paper, we compile China's household balance sheet and apply this perspective to the analysis of household financial conditions. Specifically, we first address some technical issues about the balance sheet accounts, including the coverage of household sector, main assets/liabilities items, evaluation methods, and data sources. In particular, we detail the estimations of "dwellings" and "automobiles," which, putting together, constitute the quasi-totality of household holdings of non-financial assets. Next, with the help of some financial indicators and ratios on the basis of the balance sheet information, we provide a descriptive analysis of China's households in comparison with eight major developed countries in which official national/household balance sheet data are available. In a nutshell, our findings can be summarized as: (1) China's households are still on their early stage of wealth accumulation; the asset structure, which is dominated by dwelling asset holdings, has gradually changed in favour of financial assets in recent years. (2) Although being subject to relatively low insolvency and liquidity risks, the sector has experienced, generally contrary to other countries in consideration, a climbing leverage cycle since the outbreak of the global financial crisis. This can be read as, merely from a perspective of risk, a sign of growing financial stress facing China's households.

Despite the roughness of the balance sheet information, some policy implications for China can be drawn from the analysis. First, to achieve rapid accumulation of household wealth, rapid economic growth is important but not all important. Further policy efforts should also be aimed at improving the income share of private agents. In broad outline, they include the individual / corporate income tax reform, protection of property rights, and rearrangement of rural land tenure and transferal given the state or collective ownership of land. It is to stress that these wealth/income-friendly reforms will contribute to not only the well-being of households (both in urban and rural areas), 
but the transition to a consumption-led economy - a goal topping the agenda in China's ongoing structural transformation. Moreover, it is obvious that household wealth also requires good management and reasonable allocation, which are crucial to enhancing the value of wealth, and, more particularly, to improving its structure in terms of both liquidity and risk diversification. In this regard, under effective and flexible regulations, financial services (including off-balance sheet activities) and securities markets should be designed for offering households a large amount of safe, profitable, and liquid financial assets. It is of importance to note that this structural change will further help to mitigate the overdependence of household wealth on dwellings, which has become a key focus of risk assessment and control in today's China.

Turning to the debts, although the relatively low level of leverage reflects a significant cushion for risk exposures, high attention needs to be paid to the increasing indebtedness of China's households, which is further threatened by the country's economic slowdown over the past five years or so. In such a context, to avoid and mitigate systemic financial risk, especially a prospect of US-like "subprime lending crisis," strict credit standards should be set or maintained on mortgage loans despite the recent policy commitment and implementation on the real estate destocking. Moreover, to tackle the potential risk contagion, conventional bank stress tests with extreme assumptions about asset prices and other financial parameters are highly necessary but insufficient. For instance, the dynamics of the financial institutions' behaviour to shocks and their interactions with other sectors need more consideration in the test designing, whereas those two elements, as recently pointed out in Dees et al. (2017), are so far largely overlooked in the international practice of macro-prudential measures. Additionally, given the dominant status of China's public sector, it is also important to consider what the government (central and local) and the monetary authority should or can do in the assumed adverse scenarios.

Before ending the paper, we add three caveats that have important implications and relevance for future avenues of research. First, broadly speaking, since the national / balance sheet accounts are far less standardized worldwide than the conventional accounts of flows, especially those of national income, the data and conceptual frameworks of the countries examined in the paper are not perfectly comparable with each other (for instance, rather different treatments of land and other natural resources). Hence, considering the lack of precision in our comparative analysis, we would like to draw the readers' attention more particularly to the trend than to the level of the indicators and ratios examined here. Also, it is hoped that our tentative work could pave some way for further adjustments aimed at improving the comparability of the relevant data, concepts, and methods.

The second caveat is about the stage of development, which is certainly a factor at play to account for the finding that the household leverage cycles in China substantially differ from those in the sampled developed countries. This sort of "asynchronization" of cycles is deeply rooted in the heterogeneity between China and the developed countries in many aspects, such as engines of economic growth, endowment and industrial structures, extent of financial deepening, taxation and income distribution system, and many other dimensions of socioeconomic development. In view of that, 
the combined efforts of academia, national statistical authorities, and international organizations, are sorely needed to get available more and better balance sheet data covering economies of different income levels or other characteristics. Relatedly, from a theoretical standpoint, this will also provide a novel perspective to understanding the path and structural features of economic development and social changes.

Finally, the descriptions and judgments made in this paper rely exclusively upon data at country-level. Obviously, there is no doubt that various regions and groups of people (for instance, classified by income group) within a country are usually associated with different financial conditions, and in particular, exhibit asynchronous leverage cycles. Hence, they may differ in terms of policy limitations, instruments, and goals. Moreover, the aggregated data do not allow an investigation into the distributive features of wealth and debts (thus risks) across regions and cohorts, which undoubtedly constitute another research topic of paramount importance (for a recent preliminary work on this, see Piketty et al., 2017). With all these concerns in mind, future research will greatly benefit from being associated or contrasted with studies of regional statistics and family survey, thereby drawing a more detailed portrait of the sector with heterogeneous inside.

\section{References}

Ahrend, R., and Goujard, A. (2012), International capital mobility and financial fragility - Part 1. Drivers of systemic banking crises: The role of bank-balance-sheet contagion and financial account structure, OECD Economics Department Working Papers, No. 902.

Akerlof, George A. (1970). The market for 'Lemons': Quality uncertainty and the market mechanism, Quarterly Journal of Economics, Vol. 84 (3), 488-500.

Allen, Mark, Rosenberg, Christoph, Keller, Christian, Setser, Brad, and Roubini, Nouriel (2002), A balance sheet approach to financial crisis, IMF Working Paper, WP/02/210.

Bai, Chong-en, and Qian, Zhenjie (2009), Factor income share in China: The story behind the statistics, Economic Research Journal (Chinese), Vol.44(3), 27-41.

Caballero, Ricardo J., Takeo Hoshi and Anil K. Kashyap (2008), Zombie lending and depressed restructuring in Japan, American Economic Review, 98(5), pp. 1943-1977.

Cao, Yuanzheng, and Ma, Jun (2012), Investigating national balance sheet, Caijing Magazine (Chinese), No.15.

Chen, Changbing (2014), Estimation of variable depreciation rate and measurement of capital stock, Economic Research Journal (Chinese), Vol.49 (12), 72-85.

China Association of Automobile Manufacturers (various issues), China Automotive Industry Yearbook. Beijing: China Automotive Industry Yearbook House.

Dees, S., Henry, J., and Martin, R. (2017), STAMPE: Stress-Test Analytics for Macroprudential Purposes in the Euro Area. Frankfurt: European Central Bank.

Dickinson, F., and Eakin, F. (1936), A Balance Sheet of the Nation's Economy. Urbana: University of Illinois Press.

Du, Jinfu (ed.) (2015), Government Balance Sheet: Theory and Applications in China (Chinese). Beijing: China Financial Publishing House.

Eggertsson, Gauti B. and Krugman, Paul (2012), Debt, deleveraging, and the liquidity trap: A 
Fisher-Minsky-Koo approach, Quarterly Journal of Economics, 127(3), pp. 1469-1513.

Goldsmith, R., W. (1966), The uses of national balance sheet, Review of Income and wealth, Vol.12(2), pp.95-133.

Goldsmith, Raymond W. (1982), The National Balance Sheet of the United States, 1953-1980: Chicago: The University of Chicago Press.

Goldsmith, R., W., and Lipsey, R. E. (1963), Studies in the National Balance Sheet of the United States. Princeton: Princeton University Press.

Gray, Dale F., Merton, Robert C., and Bodie, Zvi (2007), New framework for measuring and managing macrofinancial risk and financial stability, NBER Working Paper, No.13607.

Guiso, L., and Sodini, P. (2013), Household finance: An emerging field, in Constantinides, G. M., Harris, M., and Stulz, R. M. (eds.), Handbook of the Economics of Finance, Elsevier, Volume 2, Part B, Chapter 21, pp. 1397-1532.

$\mathrm{He}$, Zhiguo, Khang, In Gu, and Krishnamurthy, Arvind (2010), Balance sheet adjustments in the 2008 crisis, NBER Working Paper, No. 15919.

Ho, Samuel, and Lin, George (2003), Emerging land markets in rural and urban China: Policies and practices, China Quarterly, Vol.175 (September), pp.681-707.

Kiyotaki, Nobuhiro, and Moore, John (2002), Balance-sheet contagion, American Economic Review, Papers and Proceedings, Vol.92 (2), pp.46-50.

Koo, Richard C. (2011), The world in balance sheet recession: Causes, cure, and politics, Real World Economics Review, No. 58, pp.19-37.

Li, Yang, Zhang, Xiaojing, Chang, Xin, Tang, Duoduo, and Li, Cheng (2012a), China's sovereign balance sheet and its risk assessment: Part I, Economic Research Journal (Chinese), Vol.47(6), pp.4-19.

Li, Yang, Zhang, Xiaojing, Chang, Xin, Tang, Duoduo, and Li, Cheng (2012b), China's sovereign balance sheet and its risk assessment: Part I, Economic Research Journal (Chinese), Vol.47(7), pp.4-21.

Li, Yang, Zhang, Xiaojing, Chang, Xin, Tang, Duoduo, Li, Cheng, Wang, Jia, Zhang, Lei, Chen, Changbing, Wang, Hongju, Sun, Tao, and Liu, Xueliang (2013), National Balance Sheet of China 2013: Theory, Method, and Risk Assessment (Chinese). Beijing: China Social Sciences Press.

Li, Yang, Zhang, Xiaojing, Chang, Xin, Wang, Hongju, Tang, Duoduo, Li, Cheng, Zhang, Lei, Peng, Xingyun, Li, Yu, Liu, Xueliang, Gao, Zhanjun, and Cao, Wei (2015), National Balance Sheet of China 2015: Leverage Adjustments and Risk Management (Chinese). Beijing: China Social Sciences Press.

Lima, Juan Manuel, Montes, Enrique, Varela, Carlos, and Wiegand, Johannes (2006), Sectoral balance sheet mismatches and macroeconomic vulnerabilities in Colombia, 1996-2003, IMF Working Paper, WP/06/5.

Liu, Xiangyun, Niu, Muhong, and Yang, Ping (2009), Analysis on China's Household Balance Sheet (Chinese), Journal of Financial Research (Jin Rong Yan Jiu), No. 10, pp.107-117.

Ma, Jun, Zhang, Xiaorong, and Li, Zhiguo (2012), A Study of China's National Balance Sheet (Chinese). Beijing: Social Sciences Academic Press.

Mathisen, Johan, and Pellechio, Anthony (2006), Using the balance sheet approach in surveillance: Framework, data sources, and data availability, IMF Working Paper, WP/06/100.

National Bureau of Statistics of China (1997, 2007), Method of Compiling China's Balance Sheet 
(Chinese). Beijing: China Statistics Press.

National Bureau of Statistics of China (various issues), China Statistical Yearbook. Beijing: China Statistics Press.

Nuño, Galo, and Thomas, Carlos (2017), Bank leverage cycles, American Economic Journal: Macroeconomics, Vol. 9 (2), pp. 32-72.

Organisation for Economic Co-operation and Development (2014), Understanding National Accounts (second edition). Paris: OECD.

Paltalidis, Nikos, Gounopoulos, Dimitrios, Kizys, Renatas, and Koutelidakis, Yiannis (2015), Transmission channels of systemic risk and contagion in the European financial network, Journal of Banking and Finance, Vol.61 (supplement 1), pp. S36-S52.

People's Bank of China (PBoC) (various issues), China Financial Stability Report (CFSR). Beijing: China Financial Publishing House.

Piketty, T. (2014), Capital in the Twenty-First Century. Cambridge Mass: The Belknap Press of Harvard University.

Piketty, T., and Zucman, G (2014), Capital is back: Wealth-income ratios in rich countries, 17002010, Quarterly Journal of Economics, Vol.129 (3), pp.1255-1310.

Piketty, T., Yang, L., and Zucman, G (2017), Capital accumulation, private property and rising inequality in China, 1978-2015, NBER Working Paper, No. 23368.

Reinhart, Carmen M., Rogoff, Kenneth S., and Savastano, Miguel A. (2014), Addicted to Dollars, Annals of Economics and Finance, Vol.15 (1), pp.1-51.

Revell, Jack (1966), The national balance sheet of the United Kingdom, Review of Income and wealth, Vol.12(4), pp.281-310.

Rosenberg, Christoph, Halikias, Ioannis, House, Brett, Keller, Christian, Nystedt, Jens, Pitt, Alexander, and Setser, Brad (2005), Debt-related vulnerabilities and financial crises: An application of the balance sheet approach to emerging market countries, IMF Occasional Paper, No. 240.

Xie, Yu, Zhang, Xiaobo, Li, Jianxin, Yu, Xuejun, and Ren, Qiang (2014), China Family Panel Studies 2014 (Chinese). Beijing: Peking University Press.

Zhu, Xiaodong (2012), Understanding China's growth: Past, present, and future, Journal of Economic Perspectives, Vol.26(4), pp.103-124. 
Table 1: China's Household Balance Sheets, 2004-2014 (billion yuan, current price)

\begin{tabular}{|c|c|c|c|c|c|c|c|c|c|c|c|}
\hline Item/Year & 2004 & 2005 & 2006 & 2007 & 2008 & 2009 & 2010 & 2011 & 2012 & 2013 & 2014 \\
\hline Non-financial assets & 35213.6 & 43205.2 & 48259.1 & 60546.3 & 62218.3 & 79150.6 & 87185.1 & 104441.6 & 114969.6 & 130089.9 & 139741.8 \\
\hline -Dwellings & 32744.2 & 40298.6 & 44950.3 & 56700.3 & 57816.8 & 73911.3 & 80902.3 & 96287.5 & 105762.4 & 119873.6 & 128508.2 \\
\hline Of which: Urban & 27968 & 34374.5 & 38497.7 & 49608.5 & 50220.5 & 65592.8 & 71943.3 & 80734.8 & 89515.2 & 101146.5 & 107150 \\
\hline Rural & 4776.2 & 5924.1 & 6452.6 & 7091.8 & 7596.3 & 8318.5 & 8959 & 15552.7 & 16247.2 & 18727.1 & 21358.2 \\
\hline -Household automobiles & 1364.2 & 1596 & 1927.4 & 2357.6 & 2811.8 & 3512.3 & 4463.7 & 5445.8 & 6397.6 & 7198.9 & 7996.3 \\
\hline $\begin{array}{l}\text {-Productive fixed assets of } \\
\text { rural household }\end{array}$ & 1105.2 & 1310.6 & 1381.4 & 1488.4 & 1589.7 & 1727 & 1819.1 & 2708.3 & 2809.6 & 3017.4 & 3237.3 \\
\hline Financial assets & 18036.9 & 20908.3 & 25160 & 33549.5 & 34287 & 41086.9 & 49483.2 & $\mathbf{5 7 8 0 3 . 4}$ & 76196.4 & 90182.7 & 103151.1 \\
\hline -Currency & 1782 & 1994.5 & 2246.9 & 2521.1 & 2862.2 & 3198.2 & 3769.1 & 4265.2 & 4589.7 & 4914.7 & 5027.9 \\
\hline -Deposits & 12957.5 & 15055.1 & 17173.7 & 18184 & 22847.8 & 26865 & 31564.2 & 36333.2 & 42226.1 & 47814.9 & 52293.7 \\
\hline -Bonds & 629.3 & 653.4 & 694.4 & 670.7 & 498.1 & 262.3 & 269.2 & 189.8 & 452.7 & 864.4 & 986.8 \\
\hline -Shares & 889.7 & 786.5 & 1700.1 & 5160.4 & 2015.7 & 4737.4 & 5647.7 & 5975.5 & 6161.9 & 6238.3 & 6387.9 \\
\hline $\begin{array}{l}\text {-Shares in investment } \\
\text { funds }\end{array}$ & 190.5 & 244.9 & 561.8 & 2971.6 & 1701.1 & 838.3 & 734.6 & 795.2 & 1104.9 & 1141.8 & 1525.5 \\
\hline $\begin{array}{l}\text {-Margin account in } \\
\text { securities company }\end{array}$ & 133.9 & 156.6 & 312.8 & 990.4 & 476 & 569.5 & 444.7 & 260.7 & 219.9 & 211.4 & 415.9 \\
\hline -Insurance reserve fund & 1411.3 & 1831.5 & 2268 & 2709.7 & 3783.1 & 4622.6 & 5266.7 & 5908.4 & 7271.2 & 8587.2 & 9913.4 \\
\hline -Financial products & - & - & - & - & - & - & 1497.5 & 4075.4 & 6700 & 9500 & 13800 \\
\hline -Trust fund & - & - & - & - & - & - & 308.8 & - & 7470 & 10910 & 12800 \\
\hline -Settlement fund & -7.7 & 2.3 & 1.7 & 0 & 0 & 0 & 0 & - & - & - & - \\
\hline -Other financial assets & 50.4 & 183.5 & 200.5 & 341.5 & 103 & -6.4 & -19.3 & - & - & - & - \\
\hline Total assets & 53250.5 & 64113.5 & 73419.1 & 94095.8 & 96505.3 & 120237.5 & 136668.3 & 162245 & 191166 & 220272.6 & 242892.9 \\
\hline $\begin{array}{l}\text { Financial liabilities } \\
\text { (Loans) }\end{array}$ & 2943.1 & 3297.2 & 3963.6 & 5065.2 & 5705.8 & 8178.7 & 11254.2 & 13601.2 & 16130 & 19850.4 & 23141 \\
\hline -Non-operating loans & - & - & - & 3272.9 & 3721 & 5533.4 & 7506.4 & 8871.7 & 10435.7 & 12972.1 & 15366 \\
\hline Short-term & - & - & - & 310.4 & 413.7 & 637.8 & 956.7 & 1355.5 & 1936.7 & 2655.8 & 3249.1 \\
\hline Mid/long-term & - & - & - & 2962.5 & 3307.3 & 4895.6 & 6549.7 & 7516.2 & 8499 & 10316.3 & 12116.9 \\
\hline Of which: Mortgages & 1600 & 1840 & 2250 & 2697 & 2980 & 4420 & 5730 & 6600 & 7500 & 9000 & 10600 \\
\hline -Operating loans & - & - & - & 1792.3 & 1984.8 & 2645.3 & 3747.8 & 4729.5 & 5694.3 & 6878.3 & 7775.1 \\
\hline Short-term & - & - & - & 1279.2 & 1455.5 & 1955 & 2478.1 & 3019.8 & 3623.5 & 4358.5 & 4822.5 \\
\hline Of which: Rural & - & - & - & 1067.7 & 1197.2 & 1462.3 & - & - & - & - & - \\
\hline Mid/long-term & - & - & - & 513.1 & 529.3 & 690.3 & 1269.8 & 1709.7 & 2070.8 & 2519.7 & 2952.5 \\
\hline Net worth & $\mathbf{5 0 3 0 7 . 4}$ & 60816.3 & 69455.5 & 89030.6 & 90799.5 & 112058.8 & 125414.1 & 148643.8 & 175036 & 200422.2 & 219751.9 \\
\hline Equities & 3335.5 & 4568.7 & 6236.3 & 8832.8 & 12113.1 & 13736.5 & 17065.8 & 22050.7 & 26758.0 & 33680.7 & 39643.2 \\
\hline Total assets adjusted & 55505.8 & 67650.8 & 77393.5 & 94796.6 & 104901.6 & 128398.3 & 147351.8 & 177525.0 & 210657.2 & 246573.2 & 274622.7 \\
\hline Net worth adjusted & 52562.7 & 64353.6 & 73429.9 & 89731.4 & 99195.8 & 120219.6 & 136097.6 & 163923.8 & 194527.2 & 226722.8 & 251481.7 \\
\hline
\end{tabular}

Notes: 1. "Total assets adjusted" = "Total assets" + "Equities" - "Shares" - "Shares in investment funds".

2. "Net worth adjusted" = "Net worth" + "Equities" - "Shares" - "Shares in investment funds". 
Table 2: Estimates of China's Household Net Worth (billion yuan, current price)

\begin{tabular}{lcccccccccccc}
\hline \multicolumn{1}{c}{ Sources } & $\mathbf{2 0 0 4}$ & $\mathbf{2 0 0 5}$ & $\mathbf{2 0 0 6}$ & $\mathbf{2 0 0 7}$ & $\mathbf{2 0 0 8}$ & $\mathbf{2 0 0 9}$ & $\mathbf{2 0 1 0}$ & $\mathbf{2 0 1 1}$ & $\mathbf{2 0 1 2}$ & $\mathbf{2 0 1 3}$ & $\mathbf{2 0 1 4}$ \\
\hline -Current paper & 50307 & 60816 & 69456 & 89031 & 90800 & 112059 & 125414 & 148644 & 175036 & 200422 & 219752 \\
-Current paper, & 52563 & 64354 & 73430 & 89731 & 99196 & 120220 & 136098 & 163924 & 194527 & 226723 & 251482 \\
adjusted net worth & & & & & & & & & & \\
-Ma, et al.(2012) & 50759 & 59595 & 74007 & 95509 & 89560 & 109527 & 120816 & - & - & - & - \\
-Liu, et al. (2009) & 58754 & 70825 & 81310 & 105177 & - & - & - & - & - & - & - \\
-Xie, et al.(2014) & - & - & - & - & - & - & - & - & 188400 & - \\
-Piketty et al. (2017) & 56609 & 68777 & 81164 & 102338 & 121129 & 136468 & 168841 & 194825 & 217692 & 249140 & 274663 \\
-Piketty et al. (2017), & 50936 & 62593 & 74384 & 94572 & 112263 & 127127 & 157992 & 181995 & 203475 & 233437 & 257657 \\
excluding farmland & & & & & & & & & & \\
\hline
\end{tabular}

\section{Appendix: Household Balance Sheets of Eight Countries of Reference}

\begin{tabular}{|c|c|c|c|c|c|}
\hline Countries & $\begin{array}{l}\text { Definition/ } \\
\text { Coverage }\end{array}$ & Accounting Standards & Sources & Data Versions & Notes \\
\hline Australia & Households & $\begin{array}{l}\text { SNA 2008; Australian System of } \\
\text { National Accounts (ASNA) }\end{array}$ & $\begin{array}{l}\text { Australian Bureau of } \\
\text { Statistics }\end{array}$ & $\begin{array}{l}\text { October 30, } \\
2015\end{array}$ & June each year \\
\hline Canada & $\begin{array}{l}\text { Households } \\
\text { and NPISH }\end{array}$ & $\begin{array}{l}\text { SNA 2008; Canadian System of } \\
\text { National Accounts (CSNA) }\end{array}$ & Statistics Canada & $\begin{array}{l}\text { December } 14 \text {, } \\
2016\end{array}$ & $\begin{array}{l}\text { Fourth quarter } \\
\text { each year }\end{array}$ \\
\hline France & Households & $\begin{array}{c}\text { European System of Accounts } 2010 \\
\text { (ESA 2010) }\end{array}$ & $\begin{array}{l}\text { National Institute of Statistics } \\
\text { and Economic Studies } \\
\text { (INSEE) }\end{array}$ & $\begin{array}{l}\text { December 16, } \\
2016\end{array}$ & - \\
\hline Germany & $\begin{array}{l}\text { Households } \\
\text { and NPISH }\end{array}$ & ESA 2010 & $\begin{array}{l}\text { Federal Statistical Office } \\
\text { ( non-financial assets ) ; } \\
\text { Deutsche Bundesbank } \\
(\text { financial assets and } \\
\text { liabilities) }\end{array}$ & $\begin{array}{l}\text { September, } \\
2015\end{array}$ & - \\
\hline Italy & Households & ESA 95 & $\begin{array}{l}\text { Banca D'Italia, Supplements } \\
\text { to the Statistical Bulletin }\end{array}$ & $\begin{array}{l}\text { December } 16 \text {, } \\
2015\end{array}$ & - \\
\hline Japan & Households & $\begin{array}{c}\text { SNA 2008; National Accounts of } \\
\text { Japan }\end{array}$ & $\begin{array}{l}\text { Economic and Social } \\
\text { Research Institute (ESRI) }\end{array}$ & $\begin{array}{c}\text { January } 19, \\
2017\end{array}$ & - \\
\hline $\begin{array}{l}\text { United } \\
\text { Kingdom }\end{array}$ & $\begin{array}{l}\text { Households } \\
\text { and NPISH }\end{array}$ & ESA 2010 & Office for National Statistics & July 29, 2016 & - \\
\hline $\begin{array}{l}\text { United } \\
\text { States }\end{array}$ & $\begin{array}{l}\text { Households } \\
\text { and NPISH }\end{array}$ & $\begin{array}{l}\text { SNA 2008; Bureau of Economic } \\
\text { Analysis (BEA) National Income } \\
\text { and Product Accounts }\end{array}$ & $\begin{array}{ll}\text { BEA, } & \text { Integrated } \\
\text { Macroeconomic } & \text { Accounts } \\
\text { (IMA) } & \end{array}$ & $\begin{array}{c}\text { December } 14 \text {, } \\
2016\end{array}$ & - \\
\hline
\end{tabular}

